6

\title{
The Preparation and Stability of the ABE Teaching Workforce: Current Conditions and Future Prospects
}

\author{
M Cecil Smith
}

During an era of heightened accountability for education programs, teachers, and students, and with the connection between teacher preparation and student outcomes well established in $\mathrm{K}-12$, the adult basic education (ABE) field should be able to demonstrate that the ABE teacher workforce is qualified, competent, and able to meet the learning needs of a diverse group of adult learners. The field must achieve a consensus on strategies for creating such a workforce. We must also determine what factors will help keep ABE teachers working in the field. First, however, leaders in adult basic education must define an ideal teacher workforce.

I address five questions in this chapter:

- What should the $\mathrm{ABE}$ teacher workforce look like?

-What does the ABE teacher workforce look like now? 
- What conditions contribute to the current makeup of the ABE teacher workforce?

- What could help ABE move toward a qualified teacher workforce?

- What are the implications for research, policy, and practice that will address the issues regarding the $\mathrm{ABE}$ teacher workforce?

In order to answer these questions, I examined the literature in $\mathrm{K}-12$ teacher education, teacher certification, and teacher quality. I also reviewed surveys of ABE teachers for their data on teacher characteristics. In addition, to gather information on $\mathrm{ABE}$ teacher characteristics, I interviewed 10 program administrators responsible for hiring and supervising $\mathrm{ABE}$ teachers. The administrators were solicited via a request for assistance posted to the National Literacy Advocacy listserv. At the time of the interviews, in July 2001, the administrators I interviewed were the directors of:

- a career center in northwestern Indiana.

- a public school district's ABE center in a university community in central Illinois.

- an $\mathrm{ABE}$ program within a community college in the western Illinois Quad Cities area.

- a school district's ABE program in a midsized Louisiana city.

- an ABE program in a southeastern Texas community college.

- a community-based adult education organization in Seattle.

- a technical college basic skills program in western Washington state.

- an ABE center in Vermont.

- an adult literacy center in Philadelphia.

- a private, nonprofit adult literacy agency in western Pennsylvania.

I conducted 45- to 60-minute phone interviews with each director and asked for comments on:

1. The characteristics of the individuals they hire to teach ABE, including the individuals' skills (e.g., educational credentials, prior teaching experience), knowledge of adult learning, and competencies.

2. The administrators' ability to hire and retain ABE staff despite reported teacher shortages in the $\mathrm{K}-12$ system in some areas of the country.

3. The administrators' perceptions of the costs of developing and maintaining a qualified $\mathrm{ABE}$ teacher workforce. 


\section{WHAT SHOULD THE ABE TEACHER WORKFORCE LOOK LIKE?}

In this section, I discuss what is known about the characteristics of teachers' background and preparation that research has identified as being associated with student achievement. As the studies cited have shown, teachers indisputably have important effects on their students' learning. However, the $\mathrm{ABE}$ field has never answered the question: How much and what type of preparation is appropriate to teach adults? The ABE field must also address the stability of the teacher workforce. I suggest that qualified teachers should have an adequate understanding of instructional methods, classroom management procedures, and adult learner assessment procedures. They also should be prepared in the skills they are teaching, have knowledge of learning and disabilities, possess an appreciation of adult learner diversity, and be committed to adult education.

\section{Teacher Preparation: How Much?}

Formal Education. An examination of the literature on $\mathrm{K}-12$ teacher quality and qualifications suggests that two factors are critically important to student outcomes: specific preparation within a teacher training program and holding a teaching license (certification). Darling-Hammond (1999) defines those teachers who are trained in such programs and have a teaching certificate as "well-qualified," or highly qualified teachers. Evidence from one recent review of the empirical literature demonstrates a positive relationship between teacher education and teacher effectiveness (Wilson, Floden, \& Ferrini-Mundy, 2001), suggesting that those who embark on a teaching career should first participate in a teacher-training program (Laczko-Kerr \& Berliner, 2002). Darling-Hammond and Youngs (2002), for example, reported that several dimensions of teacher qualifications have been shown to bear a significant relationship to student achievement, including teachers' knowledge of subject matter, knowledge about teaching and learning (as reflected in their teacher-preparation experiences, including teacher education coursework), teaching experience, academic skills, and certification.

The program directors I interviewed all called for better and more consistent preparation for ABE teachers. Their sentiments were mixed, however, when it came to making certification a prerequisite for teaching ABE. Many ABE teachers have years of experience in elementary and 
secondary school classrooms but no preparation for teaching adults. Others may have extensive backgrounds working with adults in other capacities (the Peace Corps, for example) but no formal teacher training. Thus, some ABE teachers are classroom novices, whereas others are experienced educators. Several program directors I interviewed expressed the opinion that $\mathrm{ABE}$ teacher preparation can take place within the context of professional development activities - that is, once people are already working in the field. Most directors believe, however, that ABE teachers should have at least a college degree prior to teaching. Still, a degree alone does not confer the ability to be an effective basic education teacher.

Certification. Certification is the process through which states license their classroom teachers. Teacher certification processes assure the public of a teacher candidate's competence in providing instruction. Generally, to obtain K-12 certification, a candidate must have a bachelor's degree from an accredited teacher education institution, and clinical experiences (e.g., student teaching), and must pass a formal skills test, such as Praxis I and Praxis II, which are administered by the Educational Testing Service. Each state determines its certification requirements, and there is much variability across the states. Despite the lack of uniformity in credentialing teachers, most full-time $\mathrm{K}-12$ public school teachers $(93 \%)$ were fully certified in their main teaching assignment in 1998 (Lewis et al., 1999). According to data from the National Center for Education Statistics' 1993-1994 Schools and Staffing Survey (NCES, 1997a), only 5\% of teachers held provisional or probationary teaching certificates, and $2 \%$ held either temporary or emergency certificates. Usually, emergency certificates are given in order to fill teacher vacancies in areas where there are critical shortages.

How important is teacher certification to teacher effectiveness? Analyses of state-level data have demonstrated that the strongest predictor of students' achievement is the proportion of well-qualified teachers - that is, those teachers who hold full certification and a major in the field being taught (Darling-Hammond, 2000). Furthermore, teacher certification has a greater effect on achievement in subject areas such as math and science than does having a content-area bachelor's or master's degree (Goldhaber \& Brewer, 2000), and students taught by certified teachers have higher achievement than those taught by noncertified teachers (Hawk, Coble, \& Swanson, 1985). Also, certified teachers report feeling better prepared for the challenges that they face in the classroom than do noncertified teachers (Darling-Hammond, Chung, \& Frelow, 2002; Laczko-Kerr \& Berliner, 
2002). Finally, studies show that the students of teachers who acquire their credentials through nontraditional means and alternative certification procedures do not fare as well on standardized achievement tests (LaczkoKerr \& Berliner, 2002), and such teachers are more likely to leave teaching after only 2 years in the classroom (Andrew \& Schwab, 1995; Raymond, Fletcher, \& Luque, 2001). These data illustrate that K-12 teachers who hold certification are better prepared than are noncertified teachers, and students of certified teachers outperform students of noncertified teachers. Thus, the idea that ABE teachers should be certified - and perhaps certified specifically for $\mathrm{ABE}$ - is worthy of further consideration.

One survey of $\mathrm{ABE}$ professionals found general agreement with the idea that state credentialing for ABE teachers is important (Perin, 1999). Problems can arise whenever teachers are not certified, including the public's perception that uncertified teachers lack an appropriate degree and have insufficient theoretical and practical knowledge to teach well. For example, one ABE program director I interviewed described a situation in which her agency had applied for a grant to fund a back-to-school program for teenage mothers. During discussions with other supporting agencies and the local school district, a concern was raised that if the students' coursework were supervised and evaluated by ABE teachers, who are not state-certified instructors, the high school teachers might not give the students credit for their work.

The program directors in favor of certification for $\mathrm{ABE}$ teachers believed that it should be distinct from $\mathrm{K}-12$ certification. Holding certification in elementary or secondary education, they argued, is no guarantee that teachers can work successfully with adults. Still, a few directors were not convinced that better quality instruction would necessarily follow from $\mathrm{ABE}$ certification. Whether or not certification in $\mathrm{ABE}$ is ever mandated universally, ABE teachers, like their $\mathrm{K}-12$ counterparts, need ongoing professional development. Until ABE certification is required, professional development will continue to be an important vehicle for teacher preparation.

Professional Development. The goal of professional development is to improve student learning. Perin (1999) notes that professional development can be used to improve teacher competence. Competent teachers, in turn, produce competent learners (Joyce \& Showers, 1995). Experts agree that, for professional development to be effective, it must be embedded within the everyday activities of teachers, rather than offered through occasional "one-shot" workshops and seminars (National Center for Education 
Statistics, 1998), and practitioners should be "active participants in determining their own learning needs, and in designing and implementing appropriate learning activities" that contribute to their teaching abilities (Kutner \& Tibbets, 1997, p. 1).

The outcomes of professional development should be increased knowledge and improved classroom skills for teachers. Teachers should emerge from professional development training with a good grasp of learning strategies that can be imparted to students, and greater knowledge about how to teach content and assess student achievement. State departments of education require $\mathrm{K}-12$ teachers to engage in ongoing professional development activities that include attending state and regional professional conferences, local workshops, and summer institutes, and completing university courses.

\section{Teacher Preparation: What Type?}

Unique Skills and Knowledge. Teaching adults requires at least some unique skills and knowledge beyond what is required for elementary and secondary teaching. By some accounts, the learning needs of adults are considered to be fundamentally different from those of children and youth (Knowles, Holton, \& Swanson, 1998). In addition, adults in ABE programs may have a history of failure in school and can be distrustful of the educational system. ABE educators, therefore, need to be well prepared to work with the unique learning needs of $\mathrm{ABE}$ students. A significant portion of the ABE population may have undiagnosed learning disabilities, for example. Some estimates suggest that more than $50 \%$ of the ABE population may consist of adults with one or more learning disabilities (Ryan \& Price, 1993). Qualified teachers should have adequate preparation to ensure that they know how to work effectively with such learners. ABE teachers should also possess a good understanding of the core theories of adult development and learning (Merriam \& Caffarella, 1998). No research has been conducted, however, to demonstrate that teachers with specific preparation and/or certification in teaching adults, compared to teachers with $\mathrm{K}-12$ certification or teachers without any certification, are more effective in regard to student persistence and achievement.

Despite the lack of research in $\mathrm{ABE}$ about specific teacher knowledge and skills associated with teacher quality and student achievement, efforts have been made to identify important adult educator skill domains. Several states, and at least one national effort, have produced lists of competencies that describe what qualified $\mathrm{ABE}$ teachers should know and be able to do (Bureau of Adult Basic \& Literacy Education, 2001; Sherman, Tibbetts, 
Woodruff, \& Weidler, 1999). Royce (1998), for example, identified sets of teacher competencies that categorize four levels of qualification: trainee, entrance, experienced, and expert. She identified five sets of standards for competencies:

1. Adult theory in practice - creates and sustains a positive learning environment; promotes independent, lifelong learning.

2. Instructional expertise - exhibits command of content; designs and plans instruction; assesses and monitors learning.

3. Community interaction - utilizes community resources; encourages adult learner community involvement; understands the relationship between program and community.

4. Professional development - participates in professional development activities; models lifelong learning.

5. Program operations - understands the goals, policies, and procedures of agencies; exhibits accountability; functions as an effective team member.

The program directors I interviewed identified several skills as essential to effective teaching. These include the ability to individualize instruction to meet the unique and diverse learning needs of students and to diagnose student learning problems. Teachers should also possess adequate content knowledge in the areas they are teaching and have good literacy skills themselves. Although the Royce standards incorporate 13 units, 29 performance indicators, and a three-tier checklist of 139 instructor competencies, none directly addresses ABE teachers' knowledge of content.

Teaching reading is a challenging and complex activity under the best of circumstances. Knowledge of adult learner characteristics and classroom management skills alone are likely not sufficient to teach reading and related literacy skills to adult nonreaders. A recent review of the literature on $\mathrm{K}-12$ and adult reading instruction and acquisition (Kruidenier, 2002), for example, points to the use of explicit comprehension strategy instruction, multiple readings of the same text to increase reader fluency, and the need for phonemic awareness instruction with adult nonreaders. ABE teachers need to know about these instructional strategies and how to teach reading to adults. However, among the ABE teachers who hold teacher certification in $\mathrm{K}-12$, only those who have certification in elementary education are likely to have had specific coursework in reading instruction.

Some adult educators (Brookfield, 1990) disdain the search for models of effective instruction and suggest that teaching effectiveness is context- 
specific, value-laden, and not amenable to codification or standardization. Practicing adult educators, however, want to know how to increase their effectiveness and are eager to learn more about their content areas and the uses of technology, to obtain better instructional resources, and to improve their classroom management skills (D'Amico, 1995; Sabatini, Daniels, Ginsburg, Limeul, Russell, et al., 2000; Smith, Hofer, Gillespie, Solomon, \& Rowe, 2003).

In addition to a basic set of competencies and specific training or licensure related to teaching adults, adult education experts identify specific dispositions or attributes of teacher personality and character that they argue may be more important to student achievement and persistence than certification (Cantor, 2001; Johnson, 1998; Knowles et al., 1998). Dedication to adult education, patience with struggling readers, sensitivity to gender and cultural differences, enthusiasm, and the ability to convey caring feelings for students have been identified as important qualities for teachers of adults (Cantor, 2001; Galbraith, 1990; Johnson, 1998; Kazemek, 1988; Leineke \& Francisco, 1999; Shanahan, Meehan, \& Mogge, 1994). Leineke and Francisco (1999) suggest that teachers should hold high expectations for their students but be flexible, be able to cope with changing circumstances, and adapt their instructional approaches to meet student needs. Several program administrators I interviewed echoed the importance of these characteristics. They value $\mathrm{ABE}$ teachers who are able to create a sense of community in the classroom, an atmosphere that is "safe, open, and student-focused, where successes are celebrated," in the words of one $\mathrm{ABE}$ director I interviewed. Administrators indicated that they wanted to hire people who are committed to adult education; who demonstrate a positive, can-do attitude; who are ebullient, creative, open to new experiences, and able to display empathy and a sense of caring about adult learners. Such individuals are thought to be the best instructors, and several administrators agreed that they often find these personal attributes to be more important than teaching credentials or previous work experience with adults. However, I could locate no research that has tied adult student persistence, achievement, or other outcomes to such dispositions.

\section{Stability of the ABE Workforce}

Berliner (1988) and others (Ericsson \& Charness, 1994) claim that it requires up to a decade of intense, focused effort within a domain to develop expertise. Therefore, establishing an ideal teacher workforce in ABE necessitates creating conditions that encourage people to remain in the pro- 
6. PREPARATION OF THE ABE TEACHING WORKFORCE 173

fession over the long term so they can acquire both the skills and experiences to become truly expert instructors.

Despite the myriad challenges that $\mathrm{K}-12$ teachers encounter in their day-to-day practice, nearly two of every three public school teachers indicate that they plan to stay in the profession as long as they are able, or until they qualify for retirement (NCES, 1996). Only about 7\% of public and private school K-12 teachers, in fact, left the field between 1993-1994 and 1994-1995, according to data from the Schools and Staffing Survey of 1993-1994 conducted by the National Center for Education Statistics (NCES, 1997a). Thus, the K-12 teacher workforce appears to be very stable. More than $91 \%$ of public school K-12 teachers are employed fulltime as are nearly $80 \%$ of private school teachers, according to an NCES survey (NCES, 1996).

Obviously, there are characteristics of the work of teaching in $\mathrm{K}-12$ settings that make these jobs very appealing and rewarding for teachers. Slightly more than one third of teachers (33.8\%) in the 1993-1994 Schools and Staffing Survey indicated that they were "highly satisfied" with their teaching job, and another third (34.5\%) were "moderately satisfied." (By contrast, one survey of adult education staff in one metropolitan literacy program found $85 \%$ of respondents rated their jobs as "satisfactory" or "very satisfactory; D'Amico, 1995.) The factors that contribute to K-12 teacher satisfaction include having control over the work environment, having administrative support, student behavior, and teacher compensation (NCES, 1997b). It is likely that the same factors influence teacher satisfaction in $\mathrm{ABE}$ settings and play an important role in determining the overall stability of the ABE workforce.

\section{WHAT DOES THE ABE TEACHER WORKFORCE LOOK LIKE?}

As I have established, the ideal ABE workforce should be well prepared and certified. Retaining that workforce once it is in place is also crucial. Is the current workforce meeting those criteria? In this section, I describe the current conditions of $\mathrm{ABE}$ teacher preparation, and what is known about the stability of the workforce.

\section{Teacher Preparation}

Formal Education. Presently, teacher training in the ABE field primarily consists of preparation for teaching in Grades $\mathrm{K}-12$. Various 
surveys of $\mathrm{ABE}$ programs and staff find that the majority of $\mathrm{ABE}$ teachers hold teacher certification in elementary and secondary education (D’Amico, 1995; Mackin, Dwyer, Godin, Schenck, \& Seager, 1996; Sabatini et al., 2000). States' requirements for adult education are not as uniform as are those in place for $\mathrm{K}-12$ teaching, and there is little consensus as to the amount of education or training that should be required for becoming an $\mathrm{ABE}$ teacher. One program director that I interviewed hired former $\mathrm{ABE}$ and GED students as instructors (even though they did not have a high school diploma), but most states require $\mathrm{ABE}$ teachers to be certified in some field, which means that they have at least a 4-year college degree. $\mathrm{ABE}$ instructors in Alabama, for example, must hold a teaching certificate in any field and must have completed an approved master's level ABE program. Yet states such as Alaska, Colorado, and South Dakota, by contrast, have no certification or credential requirements for $\mathrm{ABE}$ teachers. Generally, even when there is no state requirement for teacher certification, such as in Hawaii, Montana, and North Dakota, there is usually either a requirement or preference for a bachelor's degree, although not necessarily in education (Kutner \& Tibbets, 1997).

Although there are little data on the subject, it appears that relatively few ABE teachers are graduates of formal programs that have been designed to prepare teachers for the ABE classroom (Mackin et al., 1996). The exception is teachers of ESOL, who often hold baccalaureate and/or graduate degrees in bilingual education or ESOL (Crandall, 1993). Individuals who earn undergraduate degrees in ESOL or bilingual education can obtain $\mathrm{K}$ 12 teacher certification in a number of states (Pelavin Associates, 1991). A survey by Pelavin Associates of college and university ABE graduate programs found no evidence of undergraduate training in ABE (Evans \& Sherman, 1999). Programs in generic adult education (which also includes human resource development) generally focus on leadership and administrative training at the graduate level. Eighty-six institutions of higher education in the United States offer graduate degrees in adult education, according to the Evans and Sherman report, but it is not clear how many of these programs specifically prepare teachers for $\mathrm{ABE}$ rather than for generic adult education.

The Mackin et al. (1996) survey of 634 adult basic educators found that $85 \%$ of surveyed personnel had earned a bachelor's or an advanced degree. Four percent had an associate's degree and 7\% had not obtained any college degree (the remaining $4 \%$ were categorized as "other"). Only $12 \%$ of the personnel surveyed by the Mackin group had earned a degree in adult education (or a closely related field). D'Amico (1995) found that 
TABLE 6.1

Educational Attainment of U.S. Adult Basic Education and Public School Teachers

\begin{tabular}{lccc}
\hline & $\begin{array}{c}<\text { Bachelor's } \\
\text { Degree }\end{array}$ & $\begin{array}{c}\text { Bachelor's } \\
\text { Degree }\end{array}$ & $\begin{array}{c}\text { Master's Credits, } \\
\text { Degrees, or Higher }\end{array}$ \\
\hline Mackin et al. (1996) $(n=634)$ & $7 \%$ & $45 \%$ & $40 \%$ \\
D'Amico (1995) $(n=360)$ & $7 \%$ & $28 \%$ & $64 \%$ \\
Sabatini et al. (2000) $(n=423)$ & $6 \%$ & $53 \%$ & $41 \%$ \\
NCES (Bandeira de Mello & $<1 \%$ & $52 \%$ & $47 \%$ \\
$\quad$ \& Broughman, 1998)* & & & \\
\hline
\end{tabular}

Note. *Data pertain to $\mathrm{K}-12$ teachers in both public and private schools.

$64 \%$ of New York City's Adult Literacy Initiative (NYCALI) paid staff had earned a master's or doctoral degree and another $28 \%$ had completed college (bachelor's degree). Among the remaining staff members having less than a 4-year college degree, $5 \%$ had not earned a high school degree (it was not clear if these staff members were teachers or held other jobs). Sabatini and colleagues (2000) reported that $41 \%$ of their sample of ABE teachers had completed a master's degree or higher, $53 \%$ had a bachelor's degree, and $6 \%$ had earned only a high school diploma or GED.

The educational credentials of the adult education teachers in these three samples compare favorably to the national population of teachers in U.S. public schools (the educational attainment of ABE teachers across the three studies, in comparison to NCES data, are shown in Table 6.1). For example, $45 \%$ of the teachers in $\mathrm{K}-12$ schools held a master's degree in 1998, according to data from the National Center for Education Statistics (Lewis et al., 1999).

Certification. ABE is one of the few fields in education in which individuals may become classroom teachers with only a modest amountperhaps only a few hours - of preparation. According to the National Institute for Literacy (2000), however, there has been a surge of interest in professionalizing the field in response to recent demands for accountability and higher standards. As a result, several states' departments of education are now moving toward requiring or recommending certification for $\mathrm{ABE}$ teachers. Whereas 20 states have no mandatory criteria for hiring adult educators, 11 states have credentialing systems in place for adult educators (Payne, Thornton, \& Falk, 2001). Each state among this latter group requires a minimum of a bachelor's degree in any field, and at least two of 
these states require certification in $\mathrm{K}-12$, as well as $\mathrm{ABE}$ certification. As previously noted, Alabama requires a master's degree in adult education. The remaining states require some adult education coursework (from 4 to 15 credits) in addition to the bachelor's degree.

Presently, there is no national uniform standard or minimum requirement for hiring teachers in ABE, although in many states, most ABE teachers who have certification hold it in either elementary or secondary education because in only a few states is ABE certification possible (Payne et al., 2001). Twenty-three states do not require $A B E$ teachers to hold teacher licenses (National Institute for Literacy, 2000).

Of the personnel surveyed by Mackin and colleagues (1996), 31\% were certified in adult education. Sixty-three percent of staff was certified in an area other than adult education. Sixty-one percent of surveyed personnel in the Sabatini et al. (2000) study were certified teachers, but they did not indicate whether they held certification in elementary, secondary, or adult education. Nearly all public school teachers are fully certified in their primary teaching field (93\% in elementary education and $92 \%$ in a departmentalized field, such as math or science), and two thirds (66\%) of high school teachers and $44 \%$ of middle school teachers have an undergraduate or graduate major in their teaching area (Lewis et al., 1999). It appears that a smaller percentage of $\mathrm{ABE}$ teachers than $\mathrm{K}-12$ teachers can be characterized as certified in $\mathrm{ABE}$.

Professional Development. Professional development should lead to increased knowledge and enhanced teaching skills that can be readily applied within the $\mathrm{ABE}$ classroom. A few states require $\mathrm{ABE}$ teachers to engage in ongoing professional development activities, including participation in state and regional conferences, workshops, and summer institutes, and to complete university coursework. Orientation programs for new $\mathrm{ABE}$ teachers are mandated in several states (Leineke \& Francisco, 1999). Typically, states' departments of education or other statelevel entities responsible for $\mathrm{ABE}$ provide these professional development workshops and programs.

The U.S. Office of Adult and Vocational Education sponsored a study that surveyed the variety of training approaches for $\mathrm{ABE}$ and $\mathrm{ESOL}$ instructors in the 50 states and the District of Columbia (Pelavin Associates, 1991). This survey found that the typical forums for professional development training are workshops, seminars, and brief training sessions, usually offered through summer institutes and conferences (Pelavin Associates, 1991; see also Belzer, Drennon, \& Smith, 2001). The content 
covered at workshops and training seminars is usually determined at the state or local level. Some states require credit or noncredit coursework that may be obtained at local colleges or universities. In most cases, these programs and seminars are directed at those already in the field, rather than individuals who are preparing to become ABE teachers.

Participants in professional development are able to obtain a smattering of knowledge in a diverse selection of topics. Typical offerings include content instruction (such as basic reading, methods of teaching mathematics, writing instruction, ESOL instruction, and life skills), adult learning theory, and the characteristics of adult learners (such as motivation, learning disabilities, learning styles, special-needs learners, and cultural diversity). Other workshop and seminar topics include methods of classroom management (such as planning for instruction), student assessment, and application of technology (Pelavin Associates, 1991). ABE teachers have expressed interest in learning about these topics (D'Amico, 1995; Sabatini et al., 2000), and they rate workshops as preferable to university coursework or online learning (Payne et al., 2001; Sabatini et al., 2000).

In states where ongoing professional development is not required, $\mathrm{ABE}$ teachers voluntarily attend workshops and seminars when they are convenient and accessible to them. Mackin et al. (1996) found that $57 \%$ of ABE staff reported having participated in statewide and/or regional conferences, and $40 \%$ took part in single-session workshops. About one third of ABE teachers in a study by Smith et al. (2003) reported that they had provided professional development training to other $\mathrm{ABE}$ teachers (e.g., leading workshops, mentoring, and coaching). The high level of participation in conferences, workshops, and training attests to ABE teachers' commitment to increasing their skills and knowledge, assisting other teachers in their professional development, and thereby helping students acquire literacy.

However, one could question the extent to which a teacher can become an expert educator through only occasional participation in workshops. Research in K-12 has documented the inability of one-shot workshops to increase teachers' knowledge and skills without follow-up or ongoing assistance for teachers once they return to their classrooms (Joyce \& Showers, 1995). Little research in K-12 exists about how teachers change as a result of professional development. Mackin et al. (1996) asked ABE teachers to list a professional development activity that had a significant impact on their work. More than one third (37\%) felt that none of the activities in which they had participated had a significant impact. Among those who rated professional development activities as significantly affecting their work, $25 \%$ said that participation in state or regional conferences 
was the primary activity. Nearly half (47\%) of Mackin et al.'s respondents indicated that participation had positive effects on curriculum and instructional methods, and $42 \%$ indicated that positive outcomes for adult students were achieved. Smith et al. (2003), in a study of ABE teacher change and professional development, found that after 18 hours of participation in professional development, most teachers gained at least some knowledge on the topic, but only $24 \%$ changed significantly over time as a result.

\section{Stability of the ABE Workforce}

Two other aspects of the makeup of the ABE teacher population describe who teachers are in this field: employment status (full-time and part-time employment) and employment stability (the amount of staff turnover and job migration within the ABE field).

A survey of adult education programs (Young, Fitzgerald, \& Morgan, 1994) reported that $41 \%$ did not employ full-time staff. One half $(50 \%)$ of the respondents in D'Amico's (1995) survey of NYCALI staff were full-time employees, although these full-time staff members were overrepresented in the sample, according to D'Amico. This was likely due to the manner in which the survey was distributed to staff, resulting in a biased sample of administrative and central-office staff members (some of whom were also ABE teachers). Seventy-two percent of the sample were employed as teachers, $22 \%$ were program managers, $8 \%$ were counselors, and $15 \%$ were employed in "other" positions. Some held multiple positions, including teaching. Most of the part-time staff members held full-time positions in other settings. Thirty-six percent of ABE teachers in the Mackin et al. (1996) survey were employed in their teaching positions on a full-time basis. Sabatini et al. (2000) reported that $59 \%$ of the ABE teachers in their survey were employed on a full-time basis (because fulltime staff were overrepresented in the Sabatini et al. study, this percentage likely overestimates the extent of full-time employment in ABE).

These data on employment status are confirmed by available federal statistics that show most ABE teachers are either employed on a parttime basis or are unpaid volunteers (U.S. Department of Education, 1999; Young et al., 1994). More than 165,000 persons worked in state-administered ABE programs in 1999, and a sizeable portion of these individuals included classroom personnel. Of this population, only $11 \%$ were fulltime staff, including program administrators, many of whom do not teach. Slightly more than 10,000 full-time teachers ( $6 \%$ of total ABE personnel) were employed in local ABE programs. 
Many teachers simultaneously work in several part-time ABE positions to achieve full-time employment (D'Amico, 1995). Some full-time elementary and secondary education teachers also moonlight as ABE teachers to supplement their incomes (Foster, 1988). Other ABE teachers are retired $\mathrm{K}-12$ teachers, and some have left public school jobs because of dissatisfaction with the work and a perceived lack of fit between their skills and the demands of teaching in public schools. Still others - particularly women - have taken extended time away from full-time teaching to raise children. While their children are young, and even once their children are older, many wish to return to the classroom and find $\mathrm{ABE}$ to be a suitable alternative because of the flexible hours offered. However, others return to $\mathrm{K}-12$ when their children are older so they can get the full-time work and employee benefits that many ABE programs are unable to offer (Smith et al., 2003).

As already indicated, a sizeable portion of the ABE teacher pool consists of part-time staff members. Although funding levels to support ABE programs and personnel have increased over time, some experts claim that these funding levels are too low to support the employment of full-time teachers (Liebowitz, Robins, \& Rubin, 2003; Sticht, 2000). Therefore, short-term employment, job migration, and high staff turnover might be expected to be the norm. However, no national random sample survey of ABE teachers has looked at the issue of turnover. D'Amico (1995) found that length of service in ABE ranged from a mean of 11 years (among staff at the NYC Board of Education) to a mean of 4 years (among City University ABE staff). (It should be noted that the mean is not the best measure for these data because the range for length of service can be very broad; the median value in the distribution for "years of present employment" is the preferable indicator. Unfortunately, this statistic was not reported.) Mackin et al. (1996) found that the average number of years in the field of ABE was 9.5 among their survey respondents, and these persons had been employed for 7.8 years, on average, at their current adult education program. Sabatini et al. (2000) reported that $65 \%$ of full-time and $57 \%$ of part-time ABE personnel had been working in the field for 6 or more years. ${ }^{1}$ No data were reported on length of service in the current teaching job. Young, Fleischman, Fitzgerald, and Morgan (1995) found that part-time ABE staff turn over more frequently than full-time staff: $80 \%$ of

\footnotetext{
${ }^{1}$ Special care should be taken when interpreting the results of this survey in terms of demographics because the researchers specifically sought to sample full-time teachers from programs identified by state staff.
} 
full-time, but only half of part-time instructors had taught in ABE for more than 3 years, meaning that half of all part-time instructors had taught in adult basic education for less than 3 years.

\section{WHAT CONDITIONS CONTRIBUTE TO THE CURRENT MAKEUP OF THE ABE TEACHER WORKFORCE?}

Compared to the ideal - a largely full-time, well-trained, and stable teaching workforce - the ABE workforce, unlike the $\mathrm{K}-12$ workforce, falls short. The majority of $\mathrm{ABE}$ teachers have not had formal preparation, work in part-time positions, and may be less experienced in teaching adults. In this section, I look at why this is the case at this time. I also look at the effects of a possible teacher shortage on the ABE workforce.

\section{Lack of Formal ABE Teacher Preparation}

As indicated previously, there are no undergraduate teacher education programs to prepare future ABE teachers. Graduates of generic adult education master's programs are likely to take full-time administrative positions, which pay more than $\mathrm{K}-12$ positions and provide benefits. Many teachers who end up in ABE programs do so because the positions offer them flexibility and freedom; they are part-time jobs that are generally free from many of the bureaucratic and curricular constraints present in $\mathrm{K}-12$ schools. Teacher education is largely post hoc in ABE, occurring through the various professional development programs that are offered to $\mathrm{ABE}$ teachers. It is through these programs that teachers first become aware of the field of adult education (Smith et al., 2003).

\section{Lack of Well-Supported Jobs in ABE}

Few incentives, such as competitive starting salaries, fringe benefits, and tenure, exist to motivate individuals to consider careers in ABE teaching. Until more powerful and attractive incentives are offered, the field will continue to rely on $\mathrm{K}-12$ teachers and others who have not been schooled in adult education. Some program directors I interviewed attributed their difficulties in hiring teachers - on either a full- or part-time basis - to the lack of competitive salaries, rather than a shortage of qualified personnel. 


\section{Dependence on Part-Time Teachers}

Many of the administrators I interviewed held the opinion that parttime teachers staff much of the ABE field. Having to rely on part-time teachers is viewed by several of the administrators as necessary because (a) funding is inadequate to support the employment of full-time teachers, (b) programs must offer classes at night for those students unable to attend during the day, and (c) student attendance is erratic, necessitating flexible class schedules. Having part-time staff allows programs to offer a variety of classes and services efficiently. Program directors noted that it would be impossible for them to offer these services without part-time teachers. For example, an adult learning center might have several small grants that fund workplace-training programs for a few hours per week on a limited basis in far-flung locations. It would be inefficient to use full-time staff to cover such piecemeal teaching assignments.

Yet this argument ignores the fact that most full-time college and university faculty members actually teach part-time (Chronicle of Higher Education, 1999) - anywhere from one to several classes per week, often at different times of the day. The remainder of their time is devoted to other responsibilities, such as research, advising students, and committee work. Although colleges are better funded than most ABE programs, the same might be possible for full-time ABE teachers. They could be flexibly deployed to teach daytime, evening, or weekend classes. Time not spent in the classroom could be devoted to other professional activities, such as curriculum development, instructional and program planning, and professional development.

One director I interviewed indicated that she hires only full-time teachers for her program because it is difficult to find suitable candidates who want to work for what she described as the low pay (and lack of benefits) that is typical of part-time teaching. She hires fewer teachers but pays them more and offers a benefits package. She had learned from previous experience that the diverse schedules and assignments of part-time teachers made it difficult to organize them into a cohesive team. Further complicating matters for program administrators, according to this director, part-time staff may teach full-time in other schools or programs, or may work in other kinds of jobs, and so are generally not available for staff meetings and often cannot or do not participate in professional development activities. Frequently, part-time teachers are unable to complete essential tasks outside the classroom, such as filling out paperwork for 
student performance assessments. This is a significant problem for program directors because documenting student progress has become critical in an era of mandated accountability.

\section{Possible Teacher Shortage}

Teacher shortages in the K-12 system may also play a role in shortages of ABE teachers. The U.S. Department of Education (2001) claims that the nation will face such a shortage of $\mathrm{K}-12$ teachers in the coming years, particularly in mathematics, science, foreign languages, ESOL, reading, and special education. There is, however, little consensus as to whether a teacher shortage exists now or is likely to develop in the near future. Feistritzer (1998), for example, points to projections from the National Center for Education Statistics that illustrate annual declines in the number of teachers that will be needed as the current school enrollment surge dissipates over the next decade. Also, more people are awarded bachelor's degrees in education each year than there are teacher vacancies, according to Feistritzer. Darling-Hammond (2000) also claims that the number of students in teacher-preparation programs each year is more than enough to satisfy the demand for teachers in the $\mathrm{K}-12$ system. These graduates represent a pool of potential $\mathrm{ABE}$ teachers and, with the proper incentives, might be encouraged to become ABE teachers.

I asked the program directors I interviewed if their efforts to find new teachers were being hurt by local teacher shortages. None believed this to be true at the present time, although a few thought that the potential for staffing problems did exist.

\section{WHAT COULD HELP MOVE ABE TOWARD A QUALIFIED TEACHER WORKFORCE?}

Moving the field toward the realization of an ideal teacher workforce will require $\mathrm{ABE}$ to train and retain qualified teachers. Establishing certification requirements is one approach; hiring experienced $\mathrm{K}-12$ teachers to work in $\mathrm{ABE}$ programs is another. Professional development can be improved so that new $\mathrm{ABE}$ teachers can quickly gear up for teaching adult learners and continue to improve their skills. 
Retaining qualified teachers may require several actions, including unionization. Collective bargaining could result in higher salaries and improved benefits, thereby making the field more attractive to potential teachers.

The ABE field can also learn and apply lessons from the early childhood education profession, particularly in regard to creating a more visible field through public awareness campaigns.

\section{Preparing an Ideal Workforce}

A report from Massachusetts, New Skills for a New Economy (Massachusetts Institute for a New Commonwealth, 2000), recommends several ways in which $\mathrm{ABE}$ might help to prepare a workforce that can meet the demands of that state's dynamic economy. These recommendations include improving teacher quality, increasing the number of full-time teachers and recruiting new teachers, increasing teacher salaries and benefits to attract a skilled teaching staff and encourage long-term commitment to the profession, and recruiting retired $\mathrm{K}-12$ public school teachers to fill part-time ABE positions. However, the report says nothing about the need for such teachers to be credentialed in ABE.

Professional development opportunities may be an appropriate avenue for experienced $\mathrm{K}-12$ teachers to acquire an ABE teaching credential. On employment in an ABE program, teachers could participate in professional development programs and courses to accumulate a sufficient number of hours to obtain ABE certification. The required number of hours of professional development will vary from state to state, although consensus regarding the minimum number of hours should be achieved. States without licensure for $\mathrm{ABE}$ teachers should consider such a requirement.

Although continuing professional education is important in most areas of teaching, it is critical to $\mathrm{ABE}$, given the diverse experience and degree of preparedness that $\mathrm{ABE}$ teachers bring to the classroom, and lack of training in reading instruction. One survey of program administrators and teachers shows professional development to be among the highest priorities for ABE teachers (Sabatini, Ginsburg, \& Russell, 2002). As already noted, several efforts have been made to identify types of teacher competencies that could be developed through staff development programs and activities (Payne et al., 2001; Royce, 1998). Once the competencies are identified and staff development programs have been put in place, proce-

dures and instruments must be established to assess the degree to which teachers have achieved these competencies. 
As yet, little effort has been made to determine how long it would take for $\mathrm{ABE}$ teachers to acquire the identified competencies or to advance from a level of minimal proficiency to "experienced" and then "expert," or "master," teacher. However, one expert, a professional development trainer who is evaluating the teacher competencies identified by Royce (1998), estimates that ABE teachers in Pennsylvania spend from 10 to 20 hours to achieve minimal proficiency in any two competency areas (Bootsie Barbour, personal communication, July 30, 2001).

Identifying requisite competencies for $\mathrm{ABE}$ teachers is useful in order to establish a more systematic approach to professional development. Program administrators and teachers can work collaboratively to achieve competency goals. Teachers can develop personal action plans and portfolios that document how they have reached the competency goals. These portfolios can be vehicles for professional planning, teacher-supervisor discussions, and teachers' self-evaluations. Program directors can also use lists of competencies as criteria for making hiring decisions or for evaluating teachers. The competencies can be combined with teacher-training activities to ensure that teacher candidates are appropriately prepared before entering the classroom.

\section{Retaining Quality Teachers}

To improve the stability and availability of quality teachers, the ABE field could consider unionizing the workforce. Some writers (Perin, 1999) have suggested that unionizing would help ABE teachers gain recognition as professional educators and receive the requisite salary increases, benefits, and other forms of compensation. In fact, some efforts at bringing $\mathrm{ABE}$ teachers into teachers' and other labor unions have been taking place, although these efforts are as yet few (D'Amico, 1995). According to Kerchner, Koppich, and Weeres (1997), "Unions are potentially powerful collaborators because they negotiate the allocation of time in school and define a teacher's ... dut[ies] ... and ... work role relationships" (p. 173). Most ABE teachers who are union members are employed in community colleges that have collective bargaining units representing the faculty and/or operating staff (although there are ABE teachers who teach union members in literacy programs run by the unions, and these teachers are sometimes also union members; National Education Association, 2001). The largest teachers' unions - the National Education Association (NEA) and the American Federation of Teachers (AFT) - appear not to 
have devoted significant attention to ABE teachers' concerns. According to Sticht (2002), NEA's Department of Adult Education separated from AFT in 1951 and joined with the American Association for Adult Education to form the Adult Education Association of the United States. Thus, for the latter half of the 20th century, NEA was removed from the adult education business altogether and from the professionalization of adult educators. ABE teachers' best hopes for unionizing may, therefore, reside with other labor organizations. Historically, the labor unions representing crafts, trades, and manufacturing employees have taken more than a passing interest in adult education, including ABE (Timm, 1996). Recently, the United Auto Workers (UAW) became the official bargaining unit for graduate assistants at New York University (Smallwood, 2001). It is not hard to imagine how the UAW or an organization such as the American Federation of County, State, and Municipal Employees (AFCSME) might come to represent the professional interests of $\mathrm{ABE}$ teachers, especially those employed in ABE programs at community colleges (D'Amico, 1995).

Unionization of ABE teachers is likely to lead to higher pay, benefits such as health care and life insurance, and more stable, longer term employment. These are the kinds of incentives that are likely to bring more qualified and committed individuals into the field. Unionization is not without its potential drawbacks, however. Among the concerns mentioned by program directors was that differences between administrators and teachers regarding professional development priorities might lead to grievance processes. Such actions could lead to fewer opportunities for teacher learning and professional development. A recent study examining contracts for $\mathrm{K}-12$ teachers in 100 school districts, for example, found that only about a quarter of these agreements contained explicit language on professional development (Bredeson, 2001). Unionization is thus no guarantee that the best interests of ABE teachers (or of their students) will be served.

To meet the unique needs of the populations they serve, above all else, $\mathrm{ABE}$ programs must be flexible. A few of the program directors I interviewed voiced concerns that union contracts might restrict class scheduling or limit teacher contact hours or class size, thus hindering the delivery of services. Also, in colleges where the faculty is represented by unions, cooperation and understanding between regular college and ABE faculties is necessary in order to avoid conflicts over issues such as course load and staff development. Because ABE teaching is distinct from college-level teaching, college faculty need to be informed about, and sympathetic to, the field's unique demands. 


\section{Lessons Learned From Early Childhood Education}

It is useful to consider what $\mathrm{ABE}$ can learn from teacher preparation initiatives in other fields. Teacher training in the field of early childhood education (ECE), for example, may have some implications for teacher preparation in $\mathrm{ABE}$. ECE shares with $\mathrm{ABE}$ many of the problems associated with trying to prepare and retain a professional workforce. The conditions of $\mathrm{ABE}$ and $\mathrm{ECE}$ teacher training, and opportunities for professional practice, are remarkably similar.

$\mathrm{ABE}$ teachers can identify with the many frustrations that early childhood educators encounter in their professional development. As is true in ECE, the attempts to professionalize ABE teachers have not been coordinated across states. Both professions are perceived to have lower status compared with other fields of education. Historically, salaries have been very low for adult and early childhood educators, and fringe benefits are poor or nonexistent (Isenberg, 2000). Neither field offers clearly defined career paths, and employment opportunities are frequently limited to parttime positions because programs lack the necessary state and federal funding to employ full-time staff. Funding disparities leave teachers in ABE and ECE vulnerable to budget cuts that threaten their jobs.

In several respects, however, ECE is ahead of $\mathrm{ABE}$ and has advanced well beyond $\mathrm{ABE}$ as a recognizable profession. The ECE field has a national organization - the National Association for the Education of Young Children (NAEYC) - that represents the interests of early childhood professionals and advocates for the provision of high-quality early childhood programs.

A major advantage of ECE over the $\mathrm{ABE}$ field is that the population served by ECE is easy to identify (i.e., children under age 5). ABE, on the other hand, serves a highly diverse population (age 16 and older) with a much broader array of learning needs.

ECE also enjoys generally widespread public support for its goal of securing the healthy development of all young children through highquality early childhood programs. In contrast, the public in general neither acknowledges nor understands the important role of $\mathrm{ABE}$, and the field has no single organization that advocates on its behalf. As ECE professionals have done in the past, $\mathrm{ABE}$ teachers should build public relations campaigns to educate the nation about the crucial contributions that highly qualified and fairly compensated professional $\mathrm{ABE}$ educators can make to the U.S. education system (Sticht, 1998). 


\section{WHAT ARE THE IMPLICATIONS FOR RESEARCH, POLICY, AND PRACTICE THAT WILL ADDRESS THE ISSUES REGARDING THE ABE TEACHER WORKFORCE?}

The final section of the chapter recommends directions in research, policy, and practice that will advance the field of $\mathrm{ABE}$ teaching by attracting and retaining qualified adult educators.

\section{Research}

It is imperative that researchers gather accurate data on four topics: characteristics of existing $\mathrm{ABE}$ teachers, the connection between preparation and teacher quality, the factors that support retention of teachers, and the connection between teacher quality and retention.

We have little knowledge of the current workforce. Without knowing $\mathrm{ABE}$ teachers' background characteristics and employment status and stability, we cannot know how far we have to move toward achieving the ideal workforce and how much money we need to invest to meet this goal. Having reliable and valid data on the characteristics of ABE teachers could help to negate stereotypes about this group of educators (such as the belief that "All you need is a degree of caring" - rather than an actual degree and specific preparation to teach adult learners). Valid data would also be useful in informing policies that influence teacher-hiring practices. The U.S. Department of Education's Office of Vocational and Adult Education should conduct a survey of a nationally representative sample of ABE staff or use the national NRS system, which collects data from each state and each program, to determine how many teachers are employed in full- and part-time teaching positions. We need data on ABE teachers' educational preparation, prior work experience with adults, certification status, and turnover rates.

Research is also needed to determine the characteristics that predict success in teaching ABE. For example, are individuals with extensive teaching experience in $\mathrm{K}-12$ schools more effective ABE teachers than teachers who do not have $\mathrm{K}-12$ teaching experience? Does having a graduate degree or specific academic preparation in adult education make a difference in teacher effectiveness? How beneficial is professional development in helping teachers use teaching techniques or strategies that 
research has proven to be effective? Are there measurable differences in the quality and effectiveness of full-time versus part-time ABE teachers (i.e., do students of full-time teachers have better outcomes and achievement than students of part-time teachers)? More research that examines the ways in which $\mathrm{ABE}$ teachers develop competencies for effective instruction needs to be conducted.

Research to determine what factors support retention should also be studied. For example, researchers should ask if there is a higher level of teacher attrition in $\mathrm{ABE}$ than in $\mathrm{K}-12$, and if so, what are the chief factors that contribute to that attrition in ABE? They should also look at what conditions within programs support $\mathrm{ABE}$ teachers to teach well, increase their professional development, and serve to lower staff turnover in those programs where high attrition exists.

\section{Policy}

Sticht (1998) argued that ABE should be recognized as the third leg of a three-part system of education in the United States, an educational system that is on par with the $\mathrm{P}-12$ and higher education systems. To be recognized as such, ABE needs qualified teachers. Research in $\mathrm{K}-12$ consistently indicates that teacher ability is significantly related to student achievement, but teacher skill is not the only critical factor. Having highly qualified teachers alone is not sufficient to ensure the quality of the ABE system (Darling-Hammond, 1997; Murnane \& Phillips, 1981; Rosenshine \& Stevens, 1986). ABE teachers must also have opportunities for full-time, well supported, and long-term employment, including access to high-quality professional development programs to continue to develop their skills, as $\mathrm{K}-12$ teachers do.

If research shows that hiring qualified teachers also leads to improved student performance, programs will likely struggle to be successful in meeting the literacy needs of adult learners unless qualified, knowledgeable teachers can be hired and retained. The effect of underprepared teachers on student achievement is unknown. Given the lack of evidence that ABE leads to significant increases in adults' literacy skills (Beder, 1999; Friedlander \& Martinson, 1996; Sheehan-Holt \& Smith, 2000), adult educators must recognize the problems inherent in the present system of teacher training. Of course, there are many influences on student learning, as has been shown in the $\mathrm{K}-12$ student achievement literature (e.g., class size, socioeconomic status, school resources, culture, and leadership, and teachers' working conditions). Still, having high-quality adult educators 
in $\mathrm{ABE}$ classrooms is fundamental to establishing an effective system of adult education.

Establishing a stable high-quality workforce of $\mathrm{ABE}$ teachers will require changes in attitudes on the part of national $\mathrm{ABE}$ policymakers, state-level bureaucrats, local program administrators, and teachers. Funding priorities must be reordered so that teacher salaries are sufficient to sustain a professional workforce and professional development activities can be fully supported. The field needs its own systems for preparing teachers for adult education, rather than relying on $\mathrm{K}-12$ preparation. Adult educators have long argued that the practices and philosophy of adult education are fundamentally different from those of primary and secondary education (Knowles et al., 1998; Lindeman, 1926/1989). Yet ironically, ABE predominantly employs part-time and volunteer teachers who lack specific preparation for instructing adult learners in literacy development.

If research results demonstrate that $\mathrm{ABE}$-certified teachers are more effective than noncertified teachers, as has been shown in $\mathrm{K}-12$, then $\mathrm{K}-12$ teachers who want to teach in $\mathrm{ABE}$ should be required to have specific $\mathrm{ABE}$ certification based on relevant coursework. The unique characteristics and needs of adult learners must be recognized and steps taken to ensure that only those with knowledge and training in adult education methods will be sanctioned to teach adult learners who are enrolled in formal, state-supported literacy education programs.

Presently, multiple pathways lead into the ABE teaching field. Although this approach may have some advantages for obtaining a diversified workforce, this strategy has also had the singular disadvantage of keeping teacher salaries low. If anyone (including those lacking education beyond high school or any formal teacher preparation) can become an ABE teacher, then why should a premium salary be paid to those individuals who hold advanced degrees and have ABE teacher training and certification?

The ABE field may be better served by restricting some of the avenues to becoming a teacher. Limiting the number of individuals who are qualified to teach may lead to more competitive salary and compensation packages. In this regard, the field needs to work closely with adult education faculty at colleges and universities to revamp and redirect graduate programs in adult education to include ABE teacher training. Efforts should also be made to establish undergraduate programs in adult teacher education. Undergraduates who might otherwise be attracted to fields such as special education, family studies, or social work could be recruited into these programs. It is likely that many college students are unaware that the field of adult education exists and so never consider it as a career choice. 
Teacher training and professional development activities should be broadened so teachers can move more fluidly between the $\mathrm{K}-12$ and $\mathrm{ABE}$ systems. If research shows that full-time teachers have better student outcomes than part-time teachers, opportunities for full-time employment must be increased. In that case, lobbying efforts must be directed toward increasing funding levels for ABE programs so these programs can employ a core of qualified, full-time teachers. Or, policymakers should put in place requirements that increase the per capita student costs.

If research shows that adequate supports (good salaries and benefits, paid professional development time) lead to attracting and retaining quality teachers, then such supports should be widespread. Job security issues must be addressed through long-term funding commitments to programs from the federal government and the states. Teachers' unions representing $\mathrm{ABE}$ teachers have an important role to play in negotiating more secure employment commitments, increased salaries, and improved benefits.

\section{Practice}

Recruiting and retaining qualified teachers to $\mathrm{ABE}$ requires several actions. First, research should provide policymakers with information they need

on what contributes to a quality, stable workforce. Second, ABE teaching must be established as a professional field that is on a par with early childhood and $\mathrm{K}-12$ teaching. Teachers must be empowered to make decisions about and to effect changes in their programs, which can happen only if they are viewed as capable professionals. Third, ABE teachers must be better compensated with comparable salaries and benefits (e.g., medical care, retirement plans) and increased job security (brought about by stable funding allocations). This may ultimately require that $\mathrm{ABE}$ teachers organize, join professional unions such as NEA, and engage in collective bargaining. Fourth, access to teaching resources and professional development activities must be improved. The development of high-level teaching skills depends on increased opportunities for collaboration with trainers and fellow teachers. ABE advocates must press for changes to federal and state policies regarding the professional development opportunities for $\mathrm{ABE}$ teachers. Fifth, professional associations such as the Commission on Adult Basic Education (COABE) should strive to increase participation of rank-and-file $\mathrm{ABE}$ teachers and work with other adult education organizations to raise the stature of the field.

For too long, $\mathrm{ABE}$ has relied on an "anyone we can get" approach to hiring teachers. This is a poor model for recruiting, developing, and retain- 
ing qualified practitioners. Steps should be taken to increase the visibility of $\mathrm{ABE}$ teaching as a legitimate career in education through public awareness campaigns. A field that concerns itself with increasing the educational, social, and economic opportunities of adults - to the betterment of a democratic society - has every right to claim legitimacy on a par with early childhood, $\mathrm{K}-12$, and higher education.

\section{REFERENCES}

Andrew, M., \& Schwab, R. L. (1995). Has reform in teacher education influenced teacher performance? An outcome assessment of graduates of eleven teacher education programs. Action in Teacher Education, 17, 43-53.

Bandeira de Mello, V., \& Broughman, S. P. (1998). 1993-1994 school and staffing survey: Selected results. Washington, DC: U.S. Department of Education.

Beder, H. (1999). The outcomes and impacts of adult literacy education in the United States. NCSALL Reports No. 6. Cambridge, MA: National Center for the Study of Adult Learning and Literacy.

Belzer, A., Drennon, C., \& Smith, C. (2001). Building professional development systems in adult basic education: Lessons from the field. In J. Comings, B. Garner, \& C. Smith (Eds.), The annual review of adult learning and literacy (Vol. 2, pp. 151-188). San Francisco: Jossey-Bass.

Berliner, D. C. (1988). The development of expertise in pedagogy. New Orleans, LA: American Association of Colleges for Teacher Education.

Bredeson, P. V. (2001). Negotiated learning: Union contracts and teacher professional development. Education Policy Analysis Archives, 9(26). Available at http://epaa.asu .edu/epaa/v9n26.html.

Brookfield, S. D. (1990). The skillful teacher. San Francisco: Jossey-Bass.

Bureau of Adult Basic \& Literacy Education. (2001). Pennsylvania adult teacher competencies: User's guide. Harrisburg, PA: Pennsylvania Department of Education.

Cantor, J. A. (2001). Delivering instruction to adult learners (Rev. ed.). Toronto, Canada: Wall \& Emerson.

Chronicle of Higher Education. (1999, September 3). Faculty attitudes and characteristics: Results of a 1998-99 survey. Chronicle of Higher Education, 46(2), A20-A21.

Crandall, J. (1993). Professionalism and professionalization of adult ESL literacy. TESOL Quarterly, 27(3), 497-515.

D’Amico, D. (1995, October). Staffing patterns in New York City Adult Literacy Initiative programs: Data and directions. New York: Literacy Assistance Center.

Darling-Hammond, L. (1997). The quality of teaching matters most. Journal of Staff Development, 18(1), 38-41.

Darling-Hammond, L. (1999). Teacher quality and student achievement: A review of state policy evidence. Seattle, WA: University of Washington.

Darling-Hammond, L. (2000). Teacher quality and student achievement. Education Policy Analysis Archives, 8(1). Available at http://epaa.asu.edu/epaa/v8n1/.

Darling-Hammond, L., Chung, R., \& Frelow, F. (2002). Variation in teacher preparation: 
How well do different pathways prepare teachers to teach? Journal of Teacher Education, 53(4), 286-302.

Darling-Hammond, L., \& Youngs, P. (2002). Defining "highly qualified teachers": What does "scientifically-based research" actually tell us? Educational Researcher, 31(9), $13-25$.

Ericsson, K. A., \& Charness, N. (1994). Expert performance: Its structure and acquisition. American Psychologist, 49, 725-747.

Evans, A., \& Sherman, R. (1999). Guide to ABE in graduate programs. Washington, DC: Pelavin Research Institute.

Feistritzer, C. E. (1998, January 28). The truth behind the "teacher shortage." The Wall Street Journal (online).

Foster, S. E. (1988). Professionalization of the adult literacy workforce. Washington, DC: Office of Educational Research and Improvement, U.S. Department of Education. (ERIC Document Reproduction Service No. ED302 680)

Friedlander, D., \& Martinson, K. (1996). Effects of mandatory basic education for adult AFDC recipients. Educational Evaluation and Policy Analysis, 18, 327-337.

Galbraith, M. W. (1990). Adult learning methods: A guide for effective instruction. Malabar, FL: Krieger.

Goldhaber, D. D., \& Brewer, J. (2000). Does teacher certification matter? High school teacher certification status and student achievement. Educational Evaluation \& Policy Analysis, 22(2), 129-145.

Hawk, P., Coble, C. R., \& Swanson, M. (1985). Certification: It does matter. Journal of Teacher Education, 36(3), 13-15.

Isenberg, J. P. (2000). The state of the art in early childhood professional preparation. In National Institute on Early Childhood Development and Education (Ed.), New teachers for a new century: The future of early childhood professional preparation (pp. 15-58). Washington, DC: U.S. Department of Education.

Johnson, D. P. (1998). Adult educators need to have enthusiasm. Adult Learning, 9(4), 11-14.

Joyce, B., \& Showers, B. (1995). Student achievement through staff development (Rev. ed.). White Plains, NY: Longman.

Kazemek, F. (1988). Necessary changes: Professional involvement in adult literacy programs. Harvard Educational Review, 58, 464-487.

Kerchner, C. T., Koppich, J. E., \& Weeres, J. G. (1997). United mind workers. San Francisco, CA: Jossey-Bass.

Knowles, M., Holton, E. F., \& Swanson, R. A. (1998). The adult learner: The definitive classic in adult education and human resource development. Woburn, MA: Butterworth-Heineman.

Kruidenier, J. (2002). Literacy assessment in adult basic education. In J. Comings, B. Garner, \& C. Smith (Eds.), Annual review of adult learning and literacy (Vol. 3, pp. 84151). San Francisco: Jossey-Bass.

Kutner, M., \& Tibbets, J. (1997). Looking to the future: Components of a comprehensive professional development system for adult educators. Washington, DC: Pelavin Research Institute.

Laczko-Kerr, I., \& Berliner, D. C. (2002). The effectiveness of Teach for America and other under-certified teachers on student academic achievement: A case of harmful public policy. Educational Policy Analysis Archives, 10(37). Available at http://epaa .asu.edu/epaa/v10n37/. 
Liebowitz, M., Robins, A., \& Rubin, J. (2003, March). Rising to the challenge: Building adult education systems in New England. Quincy, MA: Nellie May Education Foundation.

Leineke, W., \& Francisco, C. (1999). Credentialing adult educators in Illinois: A white paper for the field. Found online January 25, 2001 at http://www.coe.ilstu.edu/ipdpc/ credentialing.htm. (Document no longer available online.)

Lewis, L., Parsad, B., Carey, N., Bartfai, N., Farris, E., Smerdon, B. et al. (1999). Teacher quality: A report on the preparation and qualifications of public school teachers (NCES 1999-080). Washington, DC: U.S. Department of Education.

Lindeman, E. C. (1989). The meaning of adult education in the United States. Norman: University of Oklahoma. (Original work published 1926)

Mackin, K., Dwyer, M. C., Godin, K., Schenck, A., \& Seager, A. (1996). National evaluation of the Section 353 set-aside for teacher training and innovation in adult education. Portsmouth, NH: RMC Research Corporation.

Massachusetts Institute for a New Commonwealth. (2000). New skills for a new economy: Adult education's key role in sustaining economic growth and expanding opportunity. Cambridge, MA: MassInc.

Merriam, S., \& Caffarella, R. (1998). Learning in adulthood (2nd ed.). San Francisco: Jossey-Bass.

Murnane, R., \& Phillips, B. R. (1981). Learning by doing, vintage, and selection: Three pieces of the puzzle relating teaching experience and teaching performance. Economics of Education Review, 2, 453-465.

National Center for Education Statistics. (1996, July). Schools and staffing in the United States: A statistical profile, 1993-1994. Report No. 96-124. Washington, DC: U.S. Department of Education.

National Center for Education Statistics. (1997a, July). America's teachers: Profile of a profession, 1993-1994. Report No. 97-460. Washington, DC: U.S. Department of Education.

National Center for Education Statistics. (1997b, July). Job satisfaction among America's teachers: Effects of workplace conditions, background characteristics, and teacher compensation. Washington, DC: U.S. Department of Education.

National Center for Education Statistics. (1998, July). Toward better teaching: Professional development in 1993-1994. Report No. 98-230. Washington, DC: U.S. Department of Education.

National Education Association. (2001). Newsmakers: In the labor movement. Will parttimers win parity? NEAToday Online. Available at http://www.nea.org/neatoday/9811/ inlabr.html.

National Institute for Literacy (2000). The professionalization of adult education: Can state certification of adult educators contribute to a more professional workforce? NIFL State Policy Update. Washington, DC: Author.

Payne, E. M., Thornton, T., \& Falk, K. (2001, May). Texas adult education credential model. Available at http://cie.ci.swt.edu/credential/coverpage.htm.

Pelavin Associates. (1991, February). Study of ABE/ESL instructor training approaches: State profiles report. ED No. 338 605. Washington, DC: Office of Vocational and Adult Education.

Perin, D. (1999). Professionalizing adult literacy: Would a credential help? Journal of Adolescent and Adult Literacy, 42, 610-627. 
Raymond, M., Fletcher, S. H., \& Luque, J. (2001). Teach for America: An evaluation of teacher differences and student outcomes in Houston, Texas. Stanford, CA: The Hoover Institution, Center for Research on Education Outcomes.

Rosenshine, B., \& Stevens, R. (1986). Teaching functions. In M. C. Wittrock (Ed.), Handbook of research on teaching (3d ed., pp. 376-391). New York: Macmillan.

Royce, S. (1998). The adult teacher competencies study. Lancaster, PA: Royce and Royce.

Ryan, A. G., \& Price, L. (1993). Learning disabilities in adult basic education: A survey of current practices. Journal of Postsecondary Education and Disability, 10(3), 31-40.

Sabatini, J., Daniels, M., Ginsburg, L., Limeul, K., Russell, M., \& Stites, R. (2000). Teacher perspectives on the adult education profession: National survey findings about an emerging profession. NCAL Technical Report TR00-02. Philadelphia, PA: National Center on Adult Literacy.

Sabatini, J., Ginsburg, L., \& Russell, M. (2002). Professionalization and certification for teachers in adult basic education. In J. Comings, B. Garner, \& C. Smith (Eds.), Annual review of adult learning and literacy (Vol. 3, pp. 203-247). San Francisco, CA: JosseyBass.

Shanahan, T., Meehan, M., \& Mogge, S. (1994). The professionalization of the teacher in adult literacy education. Technical Report TR94-11. Philadelphia, PA: National Center on Adult Literacy.

Sheehan-Holt, J. K., \& Smith, M C. (2000). Does basic skills education affect adults' literacy proficiencies and reading practices? Reading Research Quarterly, 35(2), 226243.

Sherman, R., Tibbets, J., Woodruff, D., \& Weidler, D. (1999, February). Instructor competencies and performance indicators for the improvement of adult education programs. Washington, DC: U.S. Department of Education.

Smallwood, S. (2001, July 6). Success and new hurdles for T.A. unions. Chronicle of Higher Education, 47(42), A10-A12.

Smith, C., Hofer, J., Gillespie, M., Solomon, M., \& Rowe, K. (2003, November). How teachers change: A study of professional development in adult education. Cambridge, MA: National Center for the Study of Adult Learning and Literacy.

Sticht, T. G. (1998, April). Moving adult literacy education from the margins to the mainstream of educational policy and practice. Paper presented for the International Conference on How Adults Learn, Washington, DC.

Sticht, T. G. (2000, May). Examining the funding picture in $A B E$. Found online December 19, 2003, at http://www2.wgbh.org/MBCWEIS/LTC/ALRI/stichttwo.html.

Sticht, T. G. (2002). The rise of the adult education and literacy system in the United States: 1600-2000. In J. Comings, B. Garner, \& C. Smith (Eds.), Annual review of adult learning and literacy (Vol. 3, pp. 10-43). San Francisco: Jossey-Bass.

Timm, S. A. (1996). Workers' education: The connection between adult and business education. Thresholds in Education, 22(3), 13-16.

United States Department of Education. (1999). State-administered adult education program 1999 adult education personnel. Washington, DC: Office of Vocational and Adult Education.

United States Department of Education. (2001, October 2). Secretary Paige announces $\$ 31$ million in grants to recruit and train new teachers. Press release. Washington, DC: U.S. Department of Education. 
Wilson, S., Floden, R., \& Ferrini-Mundy, J. (2001). Teacher preparation research: Current knowledge, gaps, and recommendations. Seattle, WA: University of Washington.

Young, M. B., Fitzgerald, N., \& Morgan, M. A. (1994, December). National evaluation of adult education programs: Executive summary. Arlington, VA: Development Associates.

Young, M. B., Fleischman, H., Fitzgerald, N., \& Morgan, M. A. (1995). National evaluation of adult education programs: Executive summary. (Contract No. LC 90065001). Arlington, VA: Development Associates. 